Article

\title{
Dietary Exposure Assessment of Veterinary Antibiotics in Pork Meat on Children and Adolescents in Cyprus
}

\author{
Demetra Kyriakides ${ }^{1,2, * \mathbb{D}}$, Andreas C. Lazaris ${ }^{1}$, Konstantinos Arsenoglou ${ }^{2}$, Maria Emmanouil ${ }^{2}$, \\ Olympia Kyriakides ${ }^{3}$, Nikolaos Kavantzas ${ }^{1}$ and Irene Panderi ${ }^{4, *}$ (i) \\ 1 Laboratory of Pathological Anatomy, Department of Clinical and Laboratory Medicine, School of Medicine, \\ National and Kapodistrian University of Athens, 75, Mikras Asias Avenue, Goudi, 11527 Athens, Greece; \\ alazaris@med.uoa.gr (A.C.L.); nkavantz@med.uoa.gr (N.K.) \\ 2 Veterinary Services, Ministry of Agriculture, Rural Development and Environment, 1417 Nicosia, Cyprus; \\ carsenoglou@vs.moa.gov.cy (K.A.); memmanouil@vs.moa.gov.cy (M.E.) \\ 3 Archbishop Makarios III Hospital, 2012 Nicosia, Cyprus; olympiaieronym@gmail.com \\ 4 Laboratory of Pharmaceutical Analysis, Panepistimiopolis, Division of Pharmaceutical Chemistry, \\ Department of Pharmacy, National and Kapodistrian University of Athens, Zografou, 15771 Athens, Greece \\ * Correspondence: demetra.kyriakides@gmail.com (D.K.); irenepanderi@gmail.com (I.P.); \\ Tel.: +30-210-727-4820 (I.P.)
}

Received: 1 September 2020; Accepted: 13 October 2020; Published: 16 October 2020

check for updates

\begin{abstract}
In recent years, huge amounts of antibiotics have been administered to farm animals, and as a result, residues of these antibiotics can accumulate in livestock products and, once consumed, may be transmitted to humans. Farm animals' antibiotic treatment may therefore present a risk for consumers health, especially for children and adolescents. In children, the immune system is not fully developed, and thus, they are more susceptible than adults to resistant bacteria. A dietary exposure assessment was conducted on veterinary antibiotics found in raw pork meat among children and adolescents in Cyprus, since pork is the most consumed red meat in Cypriot population. The study was based on the results of the occurrence of 45 residual antibiotics in raw pork meat samples in Cyprus between 2012 and 2017 in combination with data on the consumption of pork meat on children and adolescents taken from the latest demographic report in Cyprus. Estimated daily intake (EDI) values of veterinary antibiotics for children aged 6-9 years old, were higher compared to EDI values for adolescents aged 10-17 years old. The percentage ratio of the estimated daily intake to the acceptable daily intake for all the veterinary antibiotic residues was less than 5.6. The results indicate that antibiotic residues in pork meat of inland production are below the acceptable daily intake and are of low risk to human health related to the exposure of antibiotics. Nevertheless, continuous exposure to low levels of antibiotic residues in respect to age vulnerability should be of a great concern.
\end{abstract}

Keywords: food composition; veterinary antibiotics; dietary exposure assessment; child; adolescent; pork meat; Cyprus

\section{Introduction}

The modern fight against bacterial infections dates back to the antibiotic era in the middle 1900s and to the discovery of the first antibiotics [1]. Since then, antibiotics have constantly been used not only for the treatment of various infections in humans but also in food production [2]. Huge amounts of antibiotics are constantly used as growth promoters or for prophylaxis and the treatment of infections among farm animals [3]. As a result, residues of these antibiotics can accumulate in livestock 
products and, once consumed, may then be transmitted to humans [4,5]. Exposure in low antibiotics concentrations may cause several adverse effects to human health, including toxicity, hypersensitivity, neurological disorders, gastrointestinal disturbances, and multidrug resistance and may also increase the prevalence of antibiotic resistance genes [6]. Antimicrobial resistance is a complicated phenomenon involving many interconnected factors between humans, animals, and environmental sources [7]. Multidrug-resistant bacteria are currently considered as an emerging global disease and a serious health concern [8]. In fact, antimicrobial resistance has reached alarming levels worldwide, and as a result, many of the treatments for common infections tend to be ineffective [9]. However, there is an insufficient understanding about whether or how human exposure to low concentrations of veterinary antibiotics in food affects the intestinal microflora. In children, the exposure to antibiotics is related to the development of bacterial resistance, childhood obesity and diabetes mellitus along with disturbances of glucose homeostasis [10-14]. The pharmacokinetics and pharmacodynamics of various drugs in children may differ significantly in relation to adults $[15,16]$. Certain antibiotics such as sulfonamides, chloramphenicol, and tetracyclines due to the known toxicity should not be used in neonates [17].

Effective national food control systems are crucial for the protection of the health and safety of consumers. Currently, the use of antibiotics in farm animals has been regulated worldwide, and maximum residue limits (MRLs) have been established for veterinary antibiotics in foodstuffs of animal origin [18-21]. Despite the extensive use of antibiotics in animals, reliable data about the pattern of use and the quantity of these compounds are not always available [22]. That is why it is important to monitor the concentration levels of antibiotic residues in animals and in food products of animal origin [23-31]. Studies on the quantitative risk assessment of foods provide important frameworks to address some of the issues related to the risk to human health from the intake of various residues via food [32-36]. Recently, a study on the residue concentrations and exposure levels of ethoxyquin and ethoxyquin dimer in farmed aquatic animals in Korea has been published [37]. A dietary exposure assessment study is the first step of a risk assessment procedure.

The MRL values for veterinary antibiotics in porcine tissue and pork meat as established under the European Regulation [18] and the Codex Alimentarius [19,20] must be controlled by the national veterinary authorities. Nevertheless, antibiotic residues in pork meat at concentrations above the established MRLs are still reported [38]. Pork is the most consumed red meat in Cyprus, but pig antibiotic treatment may present a risk for consumer health, especially for children and adolescents. In children the immune system is not fully developed, and thus, they are more susceptible than adults to resistant bacteria [11,39]. The risk of consuming pork meat, especially among children and adolescents, is of concern due to lack of data for the long-term bioaccumulation of these compounds. The bioaccumulation of antibiotics in humans may cause hypersensitivity reactions, gastrointestinal disorders, liver damages, mutagenicity, carcinogenicity, and reproductive toxicity [40,41]. Several studies revealed that children are widely exposed to antibiotics from dietary intake at low dosage levels [42-44]. In addition, studies in mice revealed that exposure in low concentrations of residual antibiotics during developmental periods affects the metabolism, gut microbiota, and adipogenesis, which can lead to obesity and diabetes $[45,46]$.

In light of the above, we thought that it would be of interest to conduct a dietary exposure assessment that could be used as the preliminary step of a risk assessment procedure over the consumption of pork meat among children and adolescents in the Cypriot population. When including a dietary exposure assessment, the risk assessment provides the scientific basis for the establishment of appropriate regulations and guidelines on the use of veterinary antibiotics in food producing animals. This will ensure that safety requirements will be protective for the consumers and appropriate for use in national and international scale. To this purpose, the results of the occurrence of 45 residual antibiotics in pork meat samples between 2012 and 2017, presented in our previous work by Kyriakides et al. [47], were combined with food consumption data of raw pork meat among children and adolescents in Cyprus. This study aims to clarify that a systematic exposure of antibiotics in low concentrations in early life may have negative impact in human health. At the same time, a comparison analysis is being developed in comparison with adults, since children have higher exposure levels per $\mathrm{kg}$ of 
body weight and thus are more susceptible to various residues. Based on the above the presented dietary exposure assessment to antibiotics for young population between 6 and 17 years of age is important and could help in the design of safety measures for the protection of the young population. This research proved that the antibiotic residues in pork meat of inland production are below the maximum established acceptable daily intake (ADI) and compose low direct risk to human health. Nevertheless, continuous exposure to low levels of antibiotics in respect to age vulnerability should be of a great concern, and further studies are needed.

\section{Materials and Methods}

\subsection{Pork Meat (Muscle Tissue) Sample Collection}

For six continuously years (2012-2017), among all districts of the Republic of Cyprus, 15,484 pork meat samples were collected from authorized slaughterhouses. The raw pork meat samples were collected from authorized slaughterhouses situated among the five districts of the Republic of Cyprus: Famagusta, Limassol, Nicosia, Larnaka, and Paphos. These samples were carried in polypropylene bags placed in icebox and stored at $-18^{\circ} \mathrm{C}$ before analysis.

\subsection{Chemicals and Reagents}

All solvents were of High-Performance Liquid Chromatography (HPLC) grade and purchased from E. Merck (Darmstadt, Germany). Reference standards of the veterinary antimicrobials and deuterated internal standards were of pharmaceutical purity grade and purchased from Sigma-Aldrich (St. Louis, MO, USA).

\subsection{Microbial Screening Method for the Detection of Antibiotic Residues in Slaughter Animals}

A microbial inhibitions assay, Premi ${ }^{\circledR}$ Test purchased from R-Biopharm AG (Darmstadt, Germany) was used to screen collected meat samples, since it detects a broad spectrum of the most used veterinary antibiotics in animal husbandry [48]. The Premi ${ }^{\circledR}$ Test is based on the inhibition of the growth of Bacillus stearothermophilus in the presence of antibiotic residues.

\subsection{Liquid Chromatographic-Tandem Mass Spectrometric Analysis}

Pork tissue samples were analyzed by a specific liquid chromatography tandem spectrometry method that was validated to detect and quantitate 45 commonly used veterinary antibiotics as described by Kyriakides et al. [47]. The confirmatory LC-MS/MS method was conducted on a Waters Alliance 2695/Quattro Premier ${ }^{\mathrm{TM}}$ XE mass spectrometer. The sample preparation involved homogenization, addition of a mixed solution of deuterated internal standards, and extraction with $5 \%$ trichloroacetic acid in water for aminoglycosides, fluoroquinolones, quinolones, and tetracyclines or extraction with $0.2 \mathrm{M}$ ammonium acetate solution in acetonitrile for $\beta$-lactam's, sulfonamides, macrolides, dehydroreductase inhibitor, and pleuromutilin. Chromatographic separation of tetracyclines, quinolones and aminoglycosides was carried out using a Luna C18 HST analytical column $(100 \times 20 \mathrm{~mm}$, $2.5 \mu \mathrm{m}$ particle size), while for the analysis of sulfonamides, $\beta$-lactams, macrolides, trimethoprim, and tiamulin, a Symmetry C18 Waters analytical column $(150 \times 2.1 \mathrm{~mm}, 3.5 \mu \mathrm{m}$ particle size $)$ was used. Data acquisition and analysis were performed using MassLynx ${ }^{\mathrm{TM}}$ Waters Software, Waters Corporation (Milford, MA, USA) and the OpenLynx ${ }^{\mathrm{TM}}$ Waters software Waters Corporation (Milford, MA, USA) was used for the screening, identification, and quantitation of the positive results. Data on the MRL values of these veterinary antibiotics including six aminoglycosides, three cephalosporins, seven fluoroquinolones, one quinolone, one lincosamide, three macrolides, five penicillin's, two $\beta$-lactam's, 11 sulphonamides, one dehydroreductase (DHR) inhibitor, and four tetracyclines, are presented in Table 1. 
Table 1. Veterinary antibiotics and maximum residue limits (MRLs) in porcine muscle.

\begin{tabular}{|c|c|c|}
\hline Antibiotic. & Antibiotic Class & MRL ( $\left.\mathrm{gg} \cdot \mathrm{kg}^{-1}\right)$ \\
\hline Dihydrostreptomycin & Aminoglycoside & 500 \\
\hline Gentamycin & Aminoglycoside & 50 \\
\hline Kanamycin & Aminoglycoside & 100 \\
\hline Paromomycin & Aminoglycoside & 500 \\
\hline Spectinomycin & Aminoglycoside & 300 \\
\hline Streptomycin & Aminoglycoside & 500 \\
\hline Cefalonium & Cephalosporin & N.E. ${ }^{\mathrm{i}}$ \\
\hline Cephapirin & Cephalosporin & 50 \\
\hline Cefoperazone & Cephalosporin & N.E. ${ }^{i}$ \\
\hline Ciprofloxacin & Fluoroquinolone & 100 \\
\hline Danofloxacin & Fluoroquinolone & 200 \\
\hline Enrofloxacin & Fluoroquinolone & 100 \\
\hline Flumequine & Fluoroquinolone & 200 \\
\hline Marbofloxacin & Fluoroquinolone & 150 \\
\hline Norfloxacin & Fluoroquinolone & N.E. ${ }^{i}$ \\
\hline Sarafloxacin & Fluoroquinolone & 10 \\
\hline Nalidixic acid & Quinolone & N.E. ${ }^{i}$ \\
\hline Lincomycin & Lincosamide & 100 \\
\hline Erythromycin & Macrolide & 200 \\
\hline Spiramycin & Macrolide & 200 \\
\hline Tilmicosin & Macrolide & N.E. ${ }^{i}$ \\
\hline Ampicillin & Penicillin & 50 \\
\hline Cloxacillin & Penicillin & 300 \\
\hline Dicloxacillin & Penicillin & 300 \\
\hline Penicillin-G (Benzylpenicilline) & Penicillin & 50 \\
\hline Penicillin-V (Phenoxymethylpenicillin) & Penicillin & 25 \\
\hline Nafcillin & $\beta$-lactam & N.E. ${ }^{i}$ \\
\hline Oxacillin & $\beta$-lactam & 300 \\
\hline Tiamulin & Pleuromutilin & 100 \\
\hline Sulfadiazine & Sulphonamide & 100 \\
\hline Sulfadimethoxine & Sulphonamide & 100 \\
\hline Sulfadimidine & Sulphonamide & 100 \\
\hline Sulfadoxine & Sulphonamide & 100 \\
\hline Sulfamerazine & Sulphonamide & 100 \\
\hline Sulfamethoxazole & Sulphonamide & 100 \\
\hline Sulfamethoxypyridazine & Sulphonamide & 100 \\
\hline Sulfanilamide & Sulphonamide & 100 \\
\hline Sulfaguanidine & Sulphonamide & 100 \\
\hline Sulfaquinoxaline & Sulphonamide & 100 \\
\hline Sulfathiazole & Sulphonamide & 100 \\
\hline Trimethoprim & Dehydroreductase inhibitor & 50 \\
\hline Chlortetracycline & Tetracyclines & 100 \\
\hline Doxycycline & Tetracyclines & 100 \\
\hline Oxytetracycline & Tetracyclines & 100 \\
\hline Tetracycline & Tetracyclines & 100 \\
\hline
\end{tabular}

${ }^{i}$ Antibiotic with not established MRL level.

\section{Results and Discussion}

\subsection{Screening and Confirmatory Results}

A microbial screening method was used for the determination of antibiotic residues in 15,484 raw pork meat samples. A total of 1766 samples suspected positive samples were analyzed by means of a tandem LC-MS/MS confirmatory method which was presented in detail in our previously published work [47]. From this research, 13 veterinary antibiotic residues including one aminoglycoside, one fluoroquinolone, one lincosamide, one macrolide, one $\beta$-lactam, 
three sulfonamides, one dehydroreductase inhibitor, and four tetracyclines were detected in 596 positive samples. In $74.6 \%$ of the positive samples ( 445 samples), all the 45 tested antibiotic residues were below MRLs. In $25.3 \%$ of the positive samples (151 samples), nine antibiotics were detected at concentration levels above the MRLs.

\subsection{Daily Consumption of Raw Pork Meat for Children and Adolescent}

The total Daily Consumption $\left(\mathrm{DC}_{\mathrm{T}}\right)$ of raw pork meat per person per family, was computed according to the following equation:

$$
\mathrm{DC}_{\mathrm{T}}=\left(\frac{((\text { annual family expenses for pork meat }) /(\text { retail selling price })) \times 1000}{365}\right)
$$

The annual family expenses for pork meat was estimated based on the statistical data of a survey conducted in 2017 by the Statistical Service of Cyprus [49]. Based on this data, the retail selling price for pork meat was $€ 4.8 / \mathrm{kg}$, and the average number of persons per family was $2.73 \pm 0.04$. Based on the above, the total daily consumption $\left(\mathrm{DC}_{\mathrm{T}}\right)$ of raw pork meat per person per family was estimated at $58.13 \mathrm{~g}$ of pork meat per person per day.

\subsection{Dietary Exposure Assessment of Veterinary Antibiotics in Children and Adolescents}

The current dietary exposure assessment was based on the results about the occurrence of 45 residual antibiotics in pork meat samples in Cyprus between 2012 and 2017 [47]. The lower-bound (LB) approach was used for the left censored data of the microbial screening method and the results below the limit of detection (LOD) were replaced by zero [50]. All the pork meat samples with antibiotics at concentrations above the established maximum residue limits (MRLs) were excluded from the exposure assessment since this pork meat is banned from the Cyprus market. In particular, the Veterinary Services of the Ministry of Agriculture, Rural Development, and Environment in Cyprus have the legal power to take appropriate measures in cases of detected residues violations, restriction or prohibition of the placing on the market; monitoring, recall, withdrawal, and/or destruction. A national program for testing of slaughtered pigs under which every animal is tested for the presence of antimicrobial residues. Animals are detained pending a result, if non-compliant, the animals are destroyed and in no case possible does the products reach the Cyprus market. Amoxycillin was therefore excluded from this study since it was detected during 2015 at a concentration range of $73.7-547 \mu \mathrm{g} \mathrm{kg}^{-1}$ and during 2016 at a concentration of $121 \mu \mathrm{g} \mathrm{kg}^{-1}$, which are above the established MRL limit in porcine muscle of $50 \mu \mathrm{g} \mathrm{kg}^{-1}$. All the analytes that were detected only once in a raw pork meat sample were also excluded. Therefore, dihydrostreptomycin and flumequine were detected only once during 2012 and 2013, respectively and they were excluded from this dietary exposure assessment. Sulfamethoxazole was detected during 2012 at a concentration range of $33.2-536 \mu \mathrm{g} \mathrm{kg}^{-1}$, during 2014 at a concentration range of $1.45-69.8 \mu \mathrm{g} \mathrm{kg}^{-1}$, and during 2015 at a concentration range of $1.45-51.8 \mu \mathrm{g} \mathrm{kg}^{-1}$. However, the acceptable daily intake (ADI) for sulfamethoxazole is not defined, and the EDI to ADI ratio was not calculated for this compound.

The estimated daily intake (EDI) of the veterinary antibiotic residues expressed in $\mu \mathrm{g} / \mathrm{kg}$ bw/day was calculated based on the following equation:

$$
\mathrm{EDI}=\frac{\mathrm{DC}_{\mathrm{T}} \times 10^{-3} \times \mathrm{C}}{\text { Average body weight } \text { per age and gender group }}
$$

where $\mathrm{DC}_{\mathrm{T}}$ is the daily consumption of pork meat in $\mathrm{g}$ per person per day, $\mathrm{C}$ is the geometric mean of the concentrations of antibiotics in pork meat expressed in $\mu \mathrm{g} / \mathrm{kg}$, and the average body weight is expressed in $\mathrm{kg}$. The EDI values were estimated for three age groups in both genders, the first ranged between 6 and 9 years old, the second between 10 and 13 years old, and the last between 14 and 
17 years old; additional information on the percentage EDI to ADI ratio for adults $18+$ years was also included in this study. Average body weight data on different age/gender groups in Cyprus have been used for this exposure assessment [51]. The average body weight for children aged 6 to 9 years old is $28.5 \mathrm{~kg}$ and $27.6 \mathrm{~kg}$ for males and females, respectively. The average body weight for adolescents aged 10 to 13 years old is $45.5 \mathrm{~kg}$ and $44.5 \mathrm{~kg}$ for males and females, respectively, and for adolescents aged 14 to 17 years old is $65.6 \mathrm{~kg}$ and $54.5 \mathrm{~kg}$ for males and females, respectively. The average weight of adults $18+$ in Cyprus is $80.9 \mathrm{~kg}$ and $64.6 \mathrm{~kg}$ for males and females, respectively.

The geometric mean of the concentrations of antibiotics was calculated for six consecutive years, and the estimated daily intake values in $\mu \mathrm{g} / \mathrm{kg}$ bw/day of antibiotic residues in the male and female young population in Cyprus between 2012 and 2017 are presented in Tables 2 and 3, respectively.

For the dietary exposure assessment, the maximum geometric mean concentration of each residue was used to calculate the representative EDI values presented in Tables 4 and 5 for males and females, respectively, as a more representative worst-case scenario.

For both males and females in all age groups, the highest EDI values were observed in 2013 for lincomycin, which ranged from $0.13 \mu \mathrm{g} / \mathrm{kg}$ bw/day to $0.30 \mu \mathrm{g} / \mathrm{kg}$ bw/day and $0.16 \mu \mathrm{g} / \mathrm{kg}$ bw/day to $0.32 \mu \mathrm{g} / \mathrm{kg}$ bw/day, respectively. Chlortetracycline, and doxycycline exhibited the second and third higher EDI values, respectively. The EDI value for chlortetracycline ranged from $0.08 \mu \mathrm{g} / \mathrm{kg} \mathrm{bw} / \mathrm{day}$ to $0.17 \mu \mathrm{g} / \mathrm{kg} \mathrm{bw} /$ day in males and $0.09 \mu \mathrm{g} / \mathrm{kg}$ bw/day to $0.18 \mu \mathrm{g} / \mathrm{kg}$ bw/day in females. For doxycycline, the EDI value ranged from $0.07 \mu \mathrm{g} / \mathrm{kg} \mathrm{bw} /$ day to $0.16 \mu \mathrm{g} / \mathrm{kg} \mathrm{bw} /$ day in males and $0.09 \mu \mathrm{g} / \mathrm{kg} \mathrm{bw} /$ day to $0.17 \mu \mathrm{g} / \mathrm{kg} \mathrm{bw} / \mathrm{day}$ in females. The EDI values for all the antibiotic residues were lower in males than in females and were ranged from $0.01 \mu \mathrm{g} / \mathrm{kg}$ bw/day to $0.30 \mu \mathrm{g} / \mathrm{kg}$ bw/day for males and $0.01 \mu \mathrm{g} / \mathrm{kg}$ bw/day to $0.32 \mu \mathrm{g} / \mathrm{kg}$ bw/day for females. EDI values were higher in children aged 6 to 9 years old than in adolescents of both groups, and these results agree with previous studies [52,53].

The EDI values and the acceptable daily intake (ADI) values of the antibiotic residues were used to calculate the percentage EDI to ADI ratio according to the Equation (3). Each ADI value is the maximum amount of a substance that a person can consume daily throughout his/her life without posing this any risk. An EDI to ADI ratio of less than unit means that the estimated daily intake of antibiotics is lower than the acceptable daily intake, i.e., no risk.

$$
\% \text { EDI to ADI ratio }=\frac{\mathrm{EDI}}{\mathrm{ADI}} \times 100
$$

The results of the \% EDI to ADI ratio are presented in Tables 4 and 5 for male and female children, respectively. Based on the analytical data of our previous work on the detection of antibiotic residues in porcine meat samples [47], we have also calculated the percentage EDI to ADI ratio for adult men and women. The plots of the \% EDI to ADI ratio versus the antibiotics for all groups including adults are presented in Figures 1 and 2.

As it can be observed in Figures 1 and 2, for both male and female adolescents in all age groups, the \% EDI to ADI ratio was less than 5.6 indicating that the consumption of pork meat in Cyprus does not pose any health risk to children and adolescents. For doxycycline, a low ADI value of $3 \mu \mathrm{g} / \mathrm{kg}$ bw is established, and the detection frequency of this substance was $34.8 \%$ during 2017 , where a maximum geometric mean concentration of $80.5 \mu \mathrm{g} \mathrm{kg}^{-1}$ was observed. The \% EDI to ADI ratio for doxycycline is higher in relation to the rest of antimicrobials; however, it is still within the acceptance limits. 
Table 2. Estimated daily intake values in $\mu \mathrm{g} / \mathrm{kg}$ body weight (bw)/day of antibiotics in male children and adolescents in Cyprus between 2012 and 2017.

\begin{tabular}{|c|c|c|c|c|c|c|c|c|c|}
\hline & 2012 & & & 2013 & & & 2014 & & \\
\hline Antimicrobial Residue & 6-9 Years & 10-13 Years & 14-17 Years & 6-9 Years & 10-13 Years & 14-17 Years & 6-9 Years & 10-13 Years & 14-17 Years \\
\hline Sulfadiazine & 0.09 & 0.05 & 0.04 & 0.02 & 0.01 & 0.01 & 0.07 & 0.04 & 0.03 \\
\hline Sulfadimidine & 0.04 & 0.02 & 0.02 & 0.02 & 0.02 & 0.01 & 0.02 & 0.01 & 0.01 \\
\hline Sulfamethoxazole & 0.10 & 0.06 & 0.04 & $<\mathrm{LOD}^{\mathrm{i}}$ & $<\mathrm{LOD}^{\mathrm{i}}$ & $<\mathrm{LOD}^{\mathrm{i}}$ & 0.01 & 0.01 & 0.01 \\
\hline Trimethoprim & 0.05 & 0.03 & 0.02 & 0.05 & 0.03 & 0.02 & 0.10 & 0.06 & 0.04 \\
\hline Lincomycin & $<\mathrm{LOD}^{\mathrm{i}}$ & $<\mathrm{LOD}^{\mathrm{i}}$ & $<\mathrm{LOD}^{\mathrm{i}}$ & 0.31 & 0.19 & 0.13 & 0.10 & 0.06 & 0.04 \\
\hline Chlortetracycline & 0.17 & 0.11 & 0.08 & 0.10 & 0.06 & 0.04 & 0.171 & 0.11 & 0.07 \\
\hline Doxycycline & 0.08 & 0.05 & 0.04 & 0.09 & 0.05 & 0.04 & $<\mathrm{LOD}^{\mathrm{i}}$ & $<\mathrm{LOD}^{\mathrm{i}}$ & $<\mathrm{LOD}^{\mathrm{i}}$ \\
\hline Oxytetracycline & 0.11 & 0.07 & 0.05 & 0.05 & 0.03 & 0.02 & 0.13 & 0.08 & 0.06 \\
\hline Tetracycline & $<\mathrm{LOD}^{\mathrm{i}}$ & $<\mathrm{LOD}^{\mathrm{i}}$ & $<\mathrm{LOD}^{\mathrm{i}}$ & $<\mathrm{LOD}^{\mathrm{i}}$ & $<\mathrm{LOD}^{\mathrm{i}}$ & $<\mathrm{LOD}^{\mathrm{i}}$ & 0.06 & 0.04 & 0.02 \\
\hline \multirow[t]{2}{*}{ Tilmicosin } & 0.02 & 0.01 & 0.01 & $<\mathrm{LOD}^{\mathrm{i}}$ & $<\mathrm{LOD}^{\mathrm{i}}$ & $<\mathrm{LOD}^{\mathrm{i}}$ & $<\mathrm{LOD}^{\mathrm{i}}$ & $<\mathrm{LOD}^{\mathrm{i}}$ & $<\mathrm{LOD}^{\mathrm{i}}$ \\
\hline & 2015 & & & 2016 & & & 2017 & & \\
\hline Antimicrobial Residue & 6-9 Years & 10-13 Years & 14-17 Years & 6-9 Years & 10-13 Years & 14-17 Years & 6-9 Years & 10-13 Years & 14-17 Years \\
\hline Sulfadiazine & 0.01 & 0.01 & 0.01 & 0.01 & 0.01 & 0.01 & 0.06 & 0.04 & 0.03 \\
\hline Sulfadimidine & 0.03 & 0.02 & 0.01 & 0.06 & 0.04 & 0.03 & $<\mathrm{LOD}^{\mathrm{i}}$ & $<\mathrm{LOD}^{\mathrm{i}}$ & $<\mathrm{LOD}^{\mathrm{i}}$ \\
\hline Sulfamethoxazole & 0.01 & 0.01 & 0.01 & $<\mathrm{LOD}^{\mathrm{i}}$ & $<\mathrm{LOD}^{\mathrm{i}}$ & $<\mathrm{LOD}^{\mathrm{i}}$ & $<\mathrm{LOD}^{\mathrm{i}}$ & $<\mathrm{LOD}^{\mathrm{i}}$ & $<\mathrm{LOD}^{\mathrm{i}}$ \\
\hline Trimethoprim & 0.05 & 0.03 & 0.02 & $<\mathrm{LOD}^{\mathrm{i}}$ & $<\mathrm{LOD}^{\mathrm{i}}$ & $<\mathrm{LOD}^{\mathrm{i}}$ & 0.04 & 0.03 & 0.02 \\
\hline Lincomycin & 0.04 & 0.03 & 0.02 & $<\mathrm{LOD}^{\mathrm{i}}$ & $<\mathrm{LOD}^{\mathrm{i}}$ & $<\mathrm{LOD}^{\mathrm{i}}$ & 0.25 & 0.16 & 0.11 \\
\hline Chlortetracycline & 0.09 & 0.06 & 0.04 & $<\mathrm{LOD}^{\mathrm{i}}$ & $<\mathrm{LOD}^{\mathrm{i}}$ & $<\mathrm{LOD}^{\mathrm{i}}$ & $<\mathrm{LOD}^{\mathrm{i}}$ & $<\mathrm{LOD}^{\mathrm{i}}$ & $<\mathrm{LOD}^{\mathrm{i}}$ \\
\hline Doxycycline & $<\mathrm{LOD}^{\mathrm{i}}$ & $<\mathrm{LOD}^{\mathrm{i}}$ & $<\mathrm{LOD}^{\mathrm{i}}$ & $<\mathrm{LOD}^{\mathrm{i}}$ & $<\mathrm{LOD}^{\mathrm{i}}$ & $<\mathrm{LOD}^{\mathrm{i}}$ & 0.16 & 0.10 & 0.07 \\
\hline Oxytetracycline & 0.07 & 0.04 & 0.03 & $<\mathrm{LOD}^{\mathrm{i}}$ & $<\mathrm{LOD}^{\mathrm{i}}$ & $<\mathrm{LOD}^{\mathrm{i}}$ & 0.05 & 0.03 & 0.02 \\
\hline Tetracycline & $<\mathrm{LOD}^{\mathrm{i}}$ & $<\mathrm{LOD}^{\mathrm{i}}$ & $<\operatorname{LOD}^{\mathrm{i}}$ & $<\operatorname{LOD}^{\mathrm{i}}$ & $<\mathrm{LOD}^{\mathrm{i}}$ & $<\mathrm{LOD}^{\mathrm{i}}$ & $<\mathrm{LOD}^{\mathrm{i}}$ & $<\operatorname{LOD}^{\mathrm{i}}$ & $<\operatorname{LOD}^{\mathrm{i}}$ \\
\hline Tilmicosin & 0.03 & 0.02 & 0.01 & 0.01 & 0.01 & 0.01 & 0.02 & 0.01 & 0.01 \\
\hline
\end{tabular}

${ }^{\mathrm{i}}$ LOD: limit of detection. 
Table 3. Estimated daily intake values in $\mu \mathrm{g} / \mathrm{kg}$ bw/day of antibiotics in female young population in Cyprus between 2012 and 2017.

\begin{tabular}{|c|c|c|c|c|c|c|c|c|c|}
\hline & 2012 & & & 2013 & & & 2014 & & \\
\hline Antimicrobial Residue & 6-9 Years & 10-13 Years & 14-17 Years & 6-9 Years & 10-13 Years & 14-17 Years & 6-9 Years & 10-13 Years & 14-17 Years \\
\hline Sulfadiazine & 0.09 & 0.06 & 0.04 & 0.02 & 0.02 & 0.01 & 0.07 & 0.04 & 0.04 \\
\hline Sulfadimidine & 0.04 & 0.02 & 0.02 & 0.02 & 0.02 & 0.01 & 0.02 & 0.01 & 0.01 \\
\hline Sulfamethoxazole & 0.11 & 0.07 & 0.05 & $<\operatorname{LOD}^{\mathrm{i}}$ & $<\operatorname{LOD}^{\mathrm{i}}$ & $<\mathrm{LOD}^{\mathrm{i}}$ & 0.01 & 0.01 & 0.01 \\
\hline Trimethoprim & 0.05 & 0.03 & 0.03 & 0.05 & 0.03 & 0.02 & 0.11 & 0.07 & 0.05 \\
\hline Lincomycin & $<\mathrm{LOD}^{\mathrm{i}}$ & $<\mathrm{LOD}^{\mathrm{i}}$ & $<\mathrm{LOD}^{\mathrm{i}}$ & 0.32 & 0.19 & 0.16 & 0.10 & 0.06 & 0.05 \\
\hline Chlortetracycline & 0.18 & 0.11 & 0.09 & 0.10 & 0.06 & 0.05 & 0.18 & 0.11 & 0.09 \\
\hline Doxycycline & 0.08 & 0.05 & 0.04 & 0.09 & 0.06 & 0.04 & $<\mathrm{LOD}^{\mathrm{i}}$ & $<\operatorname{LOD}^{\mathrm{i}}$ & $<\mathrm{LOD}^{\mathrm{i}}$ \\
\hline Oxytetracycline & 0.11 & 0.07 & 0.06 & 0.05 & 0.03 & 0.03 & 0.14 & 0.08 & 0.07 \\
\hline Tetracycline & $<\mathrm{LOD}^{\mathrm{i}}$ & $<\operatorname{LOD}^{\mathrm{i}}$ & $<\operatorname{LOD}^{\mathrm{i}}$ & $<\mathrm{LOD}^{\mathrm{i}}$ & $<\mathrm{LOD}^{\mathrm{i}}$ & $<\mathrm{LOD}^{\mathrm{i}}$ & 0.06 & 0.04 & 0.03 \\
\hline \multirow[t]{2}{*}{ Tilmicosin } & 0.02 & 0.01 & 0.01 & $<\operatorname{LOD}^{\mathrm{i}}$ & $<\mathrm{LOD}^{\mathrm{i}}$ & $<\operatorname{LOD}^{\mathrm{i}}$ & $<\mathrm{LOD}^{\mathrm{i}}$ & $<\operatorname{LOD}^{\mathrm{i}}$ & $<\mathrm{LOD}^{\mathrm{i}}$ \\
\hline & 2015 & & & 2016 & & & 2017 & & \\
\hline Antimicrobial Residue & 6-9 Years & 10-13 Years & 14-17 Years & 6-9 Years & 10-13 Years & 14-17 Years & 6-9 Years & 10-13 Years & 14-17 Years \\
\hline Sulfadiazine & 0.01 & 0.01 & 0.01 & 0.01 & 0.01 & 0.01 & 0.07 & 0.04 & 0.03 \\
\hline Sulfadimidine & 0.03 & 0.02 & 0.02 & 0.06 & 0.04 & 0.03 & $<\mathrm{LOD}^{\mathrm{i}}$ & $<\mathrm{LOD}^{\mathrm{i}}$ & $<\mathrm{LOD}^{\mathrm{i}}$ \\
\hline Sulfamethoxazole & 0.01 & 0.01 & 0.01 & $<\operatorname{LOD}^{\mathrm{i}}$ & $<\operatorname{LOD}^{\mathrm{i}}$ & $<\operatorname{LOD}^{\mathrm{i}}$ & $<\mathrm{LOD}^{\mathrm{i}}$ & $<\mathrm{LOD}^{\mathrm{i}}$ & $<\operatorname{LOD}^{\mathrm{i}}$ \\
\hline Trimethoprim & 0.05 & 0.03 & 0.02 & $<\operatorname{LOD}^{\mathrm{i}}$ & $<\mathrm{LOD}^{\mathrm{i}}$ & $<\operatorname{LOD}^{\mathrm{i}}$ & 0.04 & 0.03 & 0.02 \\
\hline Lincomycin & 0.04 & 0.03 & 0.02 & $<\mathrm{LOD}^{\mathrm{i}}$ & $<\mathrm{LOD}^{\mathrm{i}}$ & $<\mathrm{LOD}^{\mathrm{i}}$ & 0.26 & 0.16 & 0.13 \\
\hline Chlortetracycline & 0.09 & 0.06 & 0.04 & $<\operatorname{LOD}^{\mathrm{i}}$ & $<\mathrm{LOD}^{\mathrm{i}}$ & $<\operatorname{LOD}^{\mathrm{i}}$ & $<\mathrm{LOD}^{\mathrm{i}}$ & $<\operatorname{LOD}^{\mathrm{i}}$ & $<\operatorname{LOD}^{\mathrm{i}}$ \\
\hline Doxycycline & $<\mathrm{LOD}^{\mathrm{i}}$ & $<\mathrm{LOD}^{\mathrm{i}}$ & $<\mathrm{LOD}^{\mathrm{i}}$ & $<\mathrm{LOD}^{\mathrm{i}}$ & $<\mathrm{LOD}^{\mathrm{i}}$ & $<\mathrm{LOD}^{\mathrm{i}}$ & 0.17 & 0.11 & 0.09 \\
\hline Oxytetracycline & 0.07 & 0.04 & 0.04 & $<\mathrm{LOD}^{\mathrm{i}}$ & $<\mathrm{LOD}^{\mathrm{i}}$ & $<\operatorname{LOD}^{\mathrm{i}}$ & 0.05 & 0.03 & 0.02 \\
\hline Tetracycline & $<\mathrm{LOD}^{\mathrm{i}}$ & $<\mathrm{LOD}^{\mathrm{i}}$ & $<\mathrm{LOD}^{\mathrm{i}}$ & $<\mathrm{LOD}^{\mathrm{i}}$ & $<\mathrm{LOD}^{\mathrm{i}}$ & $<\mathrm{LOD}^{\mathrm{i}}$ & $<\mathrm{LOD}^{\mathrm{i}}$ & $<\mathrm{LOD}^{\mathrm{i}}$ & $<\mathrm{LOD}^{\mathrm{i}}$ \\
\hline Tilmicosin & 0.03 & 0.02 & 0.01 & 0.01 & 0.01 & 0.01 & 0.02 & 0.01 & 0.01 \\
\hline
\end{tabular}

${ }^{\mathrm{i}}$ LOD: limit of detection. 
Table 4. Estimated daily intake values (EDI) and percentage of EDI to acceptable daily intake (ADI) ratio for male children and adolescents using the maximum geometric mean concentration.

\begin{tabular}{|c|c|c|c|c|c|c|c|c|c|}
\hline \multirow[b]{2}{*}{ Antimicrobial/ADI ( $\mu \mathrm{g} / \mathrm{kg}$ bw) } & \multicolumn{2}{|c|}{ EDI ( $\mu \mathrm{g} / \mathrm{kg}$ bw/day) } & \multicolumn{7}{|c|}{ \%EDI to ADI Ratio ${ }^{\text {iii }}$} \\
\hline & Year ${ }^{i}$ & $\mathrm{C}^{\mathrm{ii}}(\mu \mathrm{g} / \mathrm{kg})$ & 6-9 Years & 10-13 Years & 14-17 Years & 6-9 Years & 10-13 Years & 14-17 Years & Adults 18+ \\
\hline Sulfadiazine/0-20 & 2012 & 42.2 & 0.09 & 0.05 & 0.04 & 0.43 & 0.27 & 0.19 & 0.15 \\
\hline Sulfadimidine/0-50 & 2016 & 28.4 & 0.06 & 0.04 & 0.02 & 0.12 & 0.07 & 0.05 & 0.04 \\
\hline Sulfamethoxazole iv & 2012 & 50.3 & 0.10 & 0.06 & 0.05 & - & - & - & - \\
\hline Trimethoprim/12.5 & 2014 & 50.9 & 0.10 & 0.06 & 0.05 & 0.83 & 0.52 & 0.36 & 0.29 \\
\hline Lincomycin/0-30 & 2013 & 149.4 & 0.31 & 0.19 & 0.13 & 1.02 & 0.64 & 0.44 & 0.36 \\
\hline Chlortetracycline/0-30 & 2012 & 84.6 & 0.17 & 0.11 & 0.08 & 0.58 & 0.36 & 0.25 & 0.20 \\
\hline Doxycycline/0-3 & 2017 & 80.5 & 0.16 & 0.10 & 0.07 & 5.47 & 3.43 & 2.38 & 1.93 \\
\hline Oxytetracycline/0-30 & 2014 & 64.5 & 0.13 & 0.08 & 0.06 & 0.44 & 0.27 & 0.19 & 0.15 \\
\hline Tetracycline/0-30 & 2014 & 28.4 & 0.06 & 0.04 & 0.02 & 0.19 & 0.12 & 0.08 & 0.07 \\
\hline Tilmicosin/0-40 & 2015 & 13.2 & 0.03 & 0.02 & 0.01 & 0.07 & 0.04 & 0.03 & 0.02 \\
\hline
\end{tabular}

i Year of the maximum concentration for the antimicrobials; ${ }^{\text {ii }}$ Geometric mean of the concentrations of antimicrobials; ${ }^{\text {iii } \% ~ E D I ~ t o ~ A D I ~ r a t i o ~ o f ~ l e s s ~ t h a n ~} 100 \%$ means that the estimated intake is lower than the acceptable intake; ${ }^{\text {iv }}$ For Sulfamethoxazole ADI value is not defined.

Table 5. Estimated daily intake values (EDI) and percentage of EDI to acceptable daily intake (ADI) ratio for female children and adolescents using the maximum geometric mean concentration.

\begin{tabular}{|c|c|c|c|c|c|c|c|c|c|}
\hline \multirow[b]{2}{*}{ Antimicrobial/ADI ( $\mu \mathrm{g} / \mathrm{kg}$ bw) } & \multirow[b]{2}{*}{ Year ${ }^{i}$} & \multirow[b]{2}{*}{$C^{\text {ii }}(\mu \mathrm{g} / \mathrm{kg})$} & \multicolumn{3}{|c|}{ EDI ( $\mu \mathrm{g} / \mathrm{kg}$ bw/ day) } & \multicolumn{4}{|c|}{ \%EDI to ADI Ratio ${ }^{\text {iii }}$} \\
\hline & & & 6-9 Years & 10-13 Years & 14-17 Years & 6-9 Years & 10-13 Years & 14-17 Years & Adults 18+ \\
\hline Sulfadiazine/0-20 & 2012 & 42.2 & 0.09 & 0.06 & 0.04 & 0.44 & 0.28 & 0.23 & 0.19 \\
\hline Sulfadimidine/0-50 & 2016 & 28.4 & 0.06 & 0.04 & 0.03 & 0.12 & 0.07 & 0.06 & 0.05 \\
\hline Sulfamethoxazole iv & 2012 & 50.3 & 0.11 & 0.07 & 0.05 & - & - & - & - \\
\hline Trimethoprim/12.5 & 2014 & 50.9 & 0.11 & 0.07 & 0.05 & 0.86 & 0.53 & 0.43 & 0.37 \\
\hline Lincomycin/0-30 & 2013 & 149.4 & 0.32 & 0.19 & 0.16 & 1.05 & 0.65 & 0.53 & 0.45 \\
\hline Chlortetracycline/0-30 & 2012 & 84.6 & 0.18 & 0.11 & 0.09 & 0.59 & 0.37 & 0.30 & 0.25 \\
\hline Doxycycline/0-3 & 2017 & 80.5 & 0.17 & 0.11 & 0.09 & 5.65 & 3.51 & 2.86 & 2.41 \\
\hline Oxytetracycline/0-30 & 2014 & 64.5 & 0.14 & 0.08 & 0.07 & 0.45 & 0.28 & 0.23 & 0.19 \\
\hline Tetracycline/0-30 & 2014 & 28.4 & 0.06 & 0.04 & 0.03 & 0.20 & 0.12 & 0.10 & 0.09 \\
\hline Tilmicosin/0-40 & 2015 & 13.2 & 0.03 & 0.02 & 0.01 & 0.07 & 0.04 & 0.04 & 0.03 \\
\hline
\end{tabular}

i Year of the maximum concentration for the antimicrobials; ii Geometric mean of the concentrations of antimicrobials; iii \% EDI to ADI ratio of less than $100 \%$ means that the estimated intake is lower than the acceptable intake; ${ }^{\text {iv }}$ For Sulfamethoxazole ADI value is not defined. 


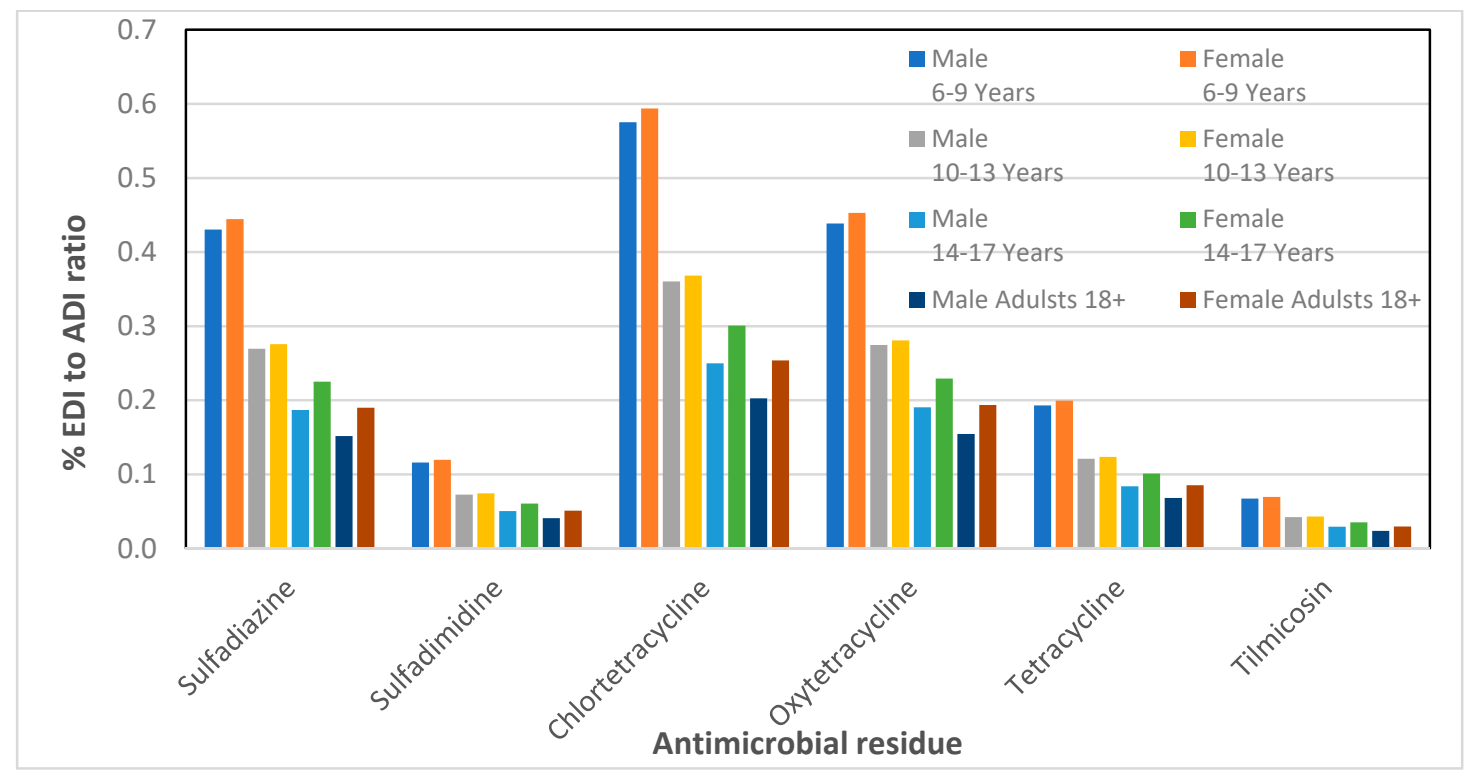

Figure 1. Percentage of estimated daily intake (EDI) to acceptable daily intake (ADI) ratio for six veterinary antibiotic residues found in pork meat for children, adolescents, and adults of the Cypriot population.

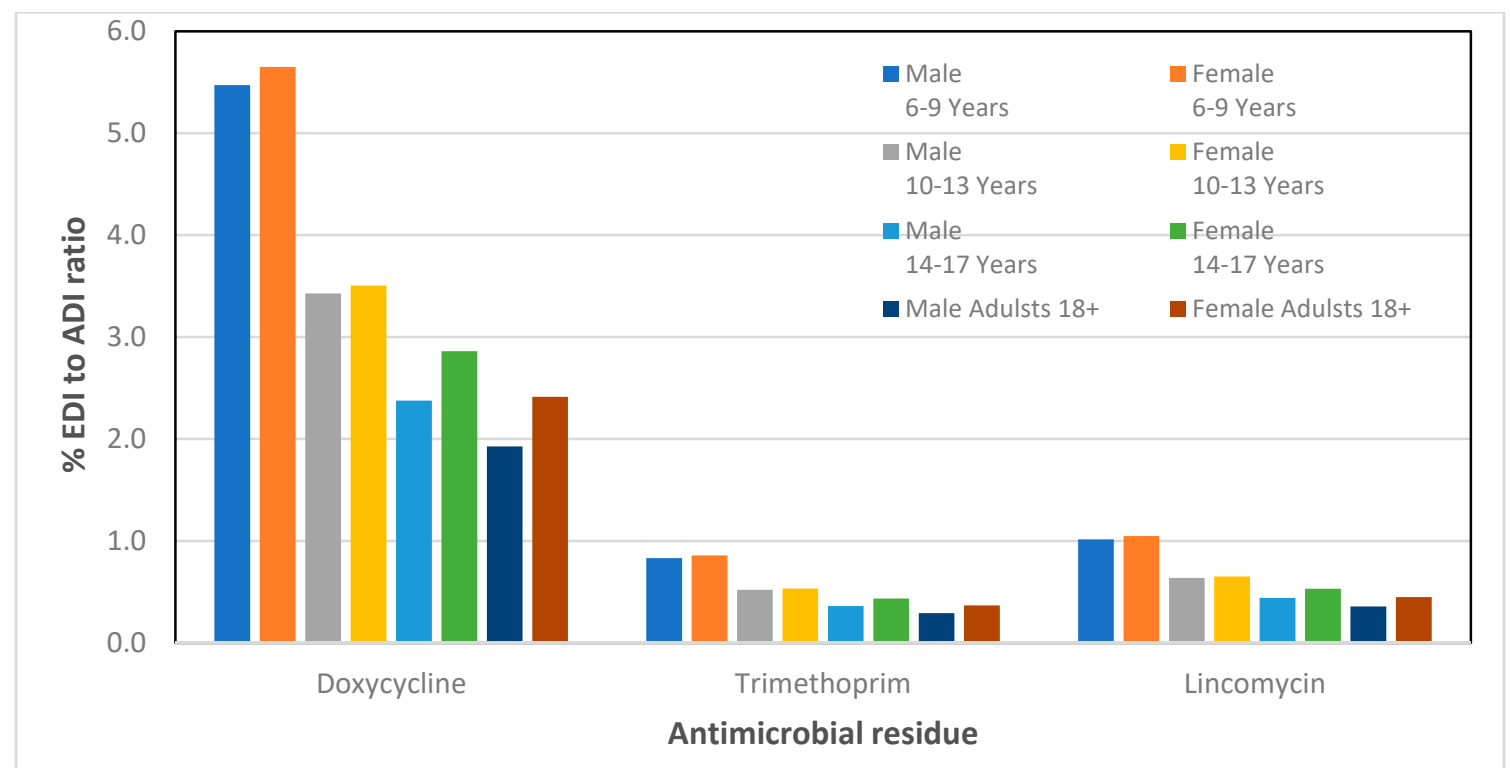

Figure 2. Percentage of estimated daily intake (EDI) to acceptable daily intake (ADI) ratio for doxycycline, trimethoprim, and lincomycin residues found in pork meat for children, adolescents, and adults of the Cypriot population.

\section{Conclusions}

In this work, a dietary exposure assessment was conducted on veterinary antibiotic residues found in raw pork meat among children and adolescents in Cyprus. The protocol of the study was based on a microbial screening method, followed by a LC-MS/MS confirmatory method [47]. The chemical analysis data were further used in a dietary exposure assessment model that was developed to estimate the daily intake of antibiotic residues through pork consumption in Cyprus for children and adolescents of both sexes. The results of this dietary exposure assessment indicate that, for all the substances, the percentage EDI to ADI ratio was less than 5.6, indicating no risk to human health. For doxycycline, the EDI to ADI ratio was higher than unit in most of the age groups. In general, the results suggest that 
pork meat does not present a potential health risk for children and adolescents aged 6-17 years old in Cyprus. However, the young consumers were more exposed to higher concentrations of antibiotic residues than adults. Children have higher body surface to body weight ratio and higher intake of calories and water compared to adults. Due to these differences in physiology compared to adults, children have higher exposure levels per $\mathrm{kg} \mathrm{bw}$, and they are more susceptible to various residues. Therefore, systematic exposure of antibiotics even in low concentrations, especially in early life, may have a negative impact in human health. That is why further investigation is strongly encouraged to protect human health, especially during developmental periods.

Author Contributions: D.K., A.C.L., N.K. and I.P. participated in designing the study. D.K., K.A., M.E. and O.K. conducted the study. Data was collected and analyzed by D.K., I.P., N.K. and A.C.L. The manuscript was written by D.K. and I.P. All authors have read and agreed to the published version of the manuscript.

Funding: This research received no external funding.

Acknowledgments: The authors would like to thank the Laboratory of Control of Food of Animal Origin (LCFAO), Veterinary Services, Ministry of Agriculture, Rural Development and Environment in Cyprus and the Veterinary Drug Residues Laboratory (VDRL), of the State General Laboratory, Ministry of Health of Cyprus. In memory of Professor George B. Foscolos, Department of Pharmacy, National and Kapodistrian University of Athens, Greece.

Conflicts of Interest: The authors declare no conflict of interest.

\section{References}

1. Aminov, R.I. A brief history of the antibiotic era: Lessons learned and challenges for the future. Front. Microbiol. 2010, 1, 134. [CrossRef] [PubMed]

2. Kirchhelle, C. Pharming animals: A global history of antibiotics in food production (1935-2017). Palgrave Commun. 2018, 4, 96. [CrossRef]

3. Martin, M.J.; Thottathil, S.E.; Newman, T.B. Antibiotics overuse in animal agriculture: A call to action for health care providers. Am. J. Public Health 2015, 105, 2409-2410. [CrossRef] [PubMed]

4. Agersø, Y.; Aarestrup, F.M.; Pedersen, K.; Seyfarth, A.M.; Struve, T.; Hasman, H. Prevalence of extended-spectrum cephalosporinase (ESC)-producing Escherichia coli in Danish slaughter pigs and retail meat identified by selective enrichment and association with cephalosporin usage. J. Antimicrob. Chemother. 2012, 67, 582-588. [CrossRef]

5. Wang, G.; Wang, B.; Zhao, X.; Xie, X.; Xie, K.; Wang, X.; Zhang, G.; Zhang, T.; Liu, X.; Dai, G. Determination of thiamphenicol, florfenicol and florfenicol amine residues in poultry meat and pork via ASE-UPLC-FLD. J. Food Compos. Anal. 2019, 81, 19-27. [CrossRef]

6. Wright, G.D. The antibiotic resistome: The nexus of chemical and genetic diversity. Nat. Rev. Microbiol. 2007, 5, 175-186. [CrossRef]

7. Anders, J.; Bisha, B. High-throughput detection and characterization of antimicrobial resistant Enterococcus $s p$. Isolates from GI Tracts of European starlings visiting concentrated animal feeding operations. Foods 2020, 9, 890. [CrossRef]

8. Medernach, L.R.; Logan, K.L. The growing threat of antibiotic resistance in children. Infect. Dis. Clin. N. Am. 2018, 32, 1-17. [CrossRef]

9. Shreiner, A.B.; Kao, J.Y.; Young, V.B. The gut microbiome in health and in disease. Curr. Opin. Gastroenterol. 2015, 31, 69-75. [CrossRef]

10. Ormerod, A.D.; Reid, T.M.; Main, R.A. Penicillin in milk-Its importance in urticaria. Clin. Exp. Allergy 1987, 17, 229-234. [CrossRef]

11. Ajslev, T.A.; Andersen, C.S.; Gamborg, M.; Sorensen, T.I.A.; Jess, T. Childhood overweight after establishment of the gut microbiota: The role of delivery mode, pre pregnancy weight and early administration of antibiotics. Int. J. Obes. 2011, 35, 522-529. [CrossRef] [PubMed]

12. Chou, H.-W.; Wang, J.-L.; Chang, C.-H.; Lee, J.-J.; Shau, W.-Y.; Lai, M.-S. Risk of severe dysglycemia among diabetic patients receiving levofloxacin, ciprofloxacin, or moxifloxacin in Taiwan. Clin. Infect. Dis. 2013, 57, 971-980. [CrossRef] [PubMed]

13. Bailey, L.; Forrest, C.B.; Zhang, P.; Richards, T.M.; Livshits, A.; DeRusso, P.A. Association of antibiotics in infancy with early childhood obesity. JAMA Pediatr. 2014, 168, 1063-1069. [CrossRef] 
14. Bacanl1, M.; Basaran, N. Importance of antibiotic residues in animal food. Food Chem. Toxicol. 2019, 125, 462-466. [CrossRef]

15. Fernandez, E.; Perez, R.; Hernandez, A.; Tejada, P.; Arteta, M.; Ramos, J.T. Factors and mechanisms for pharmacokinetic differences between pediatric population and adults. Pharmaceutics 2011, 3, 53-72. [CrossRef]

16. Dong, J.; Zhang, S.; Xia, L.; Yu, Y.; Hu, S.; Sun, J.; Zhou, P.; Chen, P. Physical activity. A critical exposure factor of environmental pollution in children and adolescents health risk assessment. Int. J. Environ. Res. Public Health 2018, 15, 176. [CrossRef]

17. Kim, D.S.; Park, M.S. Antibiotic use at a pediatric age. Yonsei Med. J. 1998, 39, 595-603. [CrossRef]

18. European Union; Regulations Commission. Pharmacologically active substances and their classification regarding maximum residue limits in foodstuffs of animal origin. REGULATION (EU) No 37/2010, 22 December 2009. Off. J. Eur. Union 2010, L15, 1-2. Available online: https://ec.europa.eu/health/sites/health/ files/files/eudralex/vol5/reg_2010_37/reg_2010_37_en.pdf (accessed on 1 March 2020).

19. FAO/WHO. Maximum Residue Limits (MRLs) and Risk Management Recommendations (RMRs) for Residues of Veterinary Drugs in Foods CAC/MRL (2-2015); Codex Alimentarius, International Food Standards: Rome, Italy, 2015.

20. FAO/WHO. Maximum Residue Limits (MRLs) and Risk Management Recommendations (RMRs) for Residues of Veterinary Drugs in Foods CX/MRL (2-2018); Codex Alimentarius, International Food Standards: Rome, Italy, 2018.

21. Tang, K.L.; Caffrey, N.P.; Nóbrega, D.P.; Cork, S.C.; Ronksley, P.E.; Barkema, H.W.; Polachek, A.J.; Ganshorn, H.; Sharma, N.; Kellner, J.D.; et al. Restricting the use of antibiotics in food-producing animals and its associations with antibiotic resistance in food-producing animals and human beings: A systematic review and meta-analysis. Lancet Planet. Health 2017, 1, e316-e327. [CrossRef]

22. Landers, T.F.; Cohen, B.; Wittum, T.E.; Larson, E.L. A review of antibiotic use in food animals: Perspective, policy, and potential. Public Health Rep. 2012, 127, 4-22. [CrossRef] [PubMed]

23. Long, A.R.; Hsieh, L.C.; Malbrough, M.S.; Short, C.R.; Barker, S.A. Multiresidue method for the determination of sulfonamides in pork tissue. J. Agric. Food Chem. 1990, 38, 423-426. [CrossRef]

24. Panderi, I.; Gerakis, A.; Zonaras, V.; Athanasiou, L.; Kazanis, M. Development and validation of a liquid chromatography-electrospray ionization mass spectrometric method for the determination of dexamethasone in sheep plasma. Anal. Chim. Acta 2004, 504, 299-306. [CrossRef]

25. Sanz, D.; Razquin, P.; Condón, S.; Juan, T.; Herraiz, B.; Mata, L. Incidence of antimicrobial residues in meat using a broad-spectrum screening strategy. Eur. J. Nutr. Food Saf. 2015, 5, 156-165. [CrossRef]

26. Guardon, M.; Miranda, J.M.; Vázquez, B.I.; Cepeda, A.; Franco, C.M. Assessment of tetracyclines residues and tetracycline resistant bacteria in conventional and organic baby foods. Foods 2015, 4, 306-317. [CrossRef]

27. Dasenaki, M.E.; Thomaidis, N.S. Multi-residue determination of 115 veterinary drugs and pharmaceutical residues in milk powder, butter, fish tissue and eggs using liquid chromatography-tandem mass spectrometry. Anal. Chim. Acta 2015, 880, 103-121. [CrossRef] [PubMed]

28. Bitas, D.; Samanidou, V. Molecularly imprinted polymers as extracting media for the chromatographic determination of antibiotics in milk. Molecules 2018, 23, 316. [CrossRef]

29. Bitas, D.; Kabir, A.; Locatelli, M.; Samanidou, V. Food sample preparation for the determination of sulfonamides by high-performance liquid chromatography: State-of-the-art. Separations 2018, 5, 31. [CrossRef]

30. Puvača, N.; Lika, E.; Tufarelli, V.; Bursić, V.; Pelić, D.L.; Nikolova, N.; Petrović, A.; Prodanović, R.; Vuković, G.; Lević, J.; et al. Influence of different tetracycline antimicrobial therapy of mycoplasma (Mycoplasma synoviae) in laying hens compared to tea tree essential oil on table egg quality and antibiotic residues. Foods 2020, 9, 612. [CrossRef]

31. Magalhães, D.; Freitas, A.; Sofia, A.; Pouca, V.; Barbosa, J.; Ramos, F. The use of ultra-high-pressure-liquid chromatography tandem time-of-flight mass spectrometry as a confirmatory method in drug residue analysis: Application to the determination of antibiotics in piglet liver. J. Chromatogr. B 2020, 115, 122264. [CrossRef] 
32. FAO/WHO. Principles and Methods for the Risk Assessment of Chemicals in Food. Chapter 6: Dietary Exposure Assessment of Chemicals in Food; FAO/WHO: Rome, Italy, 2009; Available online: https://www.who.int/ publications-detail/principles-and-methods-for-the-risk-assessment-of-chemicals-in-food (accessed on 15 December 2009).

33. Liu, S.; Zhao, G.; Zhao, H.; Zhai, G.; Chen, J.; Zhao, H. Antibiotics in a general population: Relations with gender, body mass index (BMI) and age and their human health risks. Sci. Total. Environ. 2017, 599, $298-304$. [CrossRef] [PubMed]

34. Sinanoglou, V.J.; Cavouras, D.; Xenogiannopoulos, D.; Proestos, C.; Zoumpoulakis, P. Quality assessment of pork and turkey hams using FT-IR spectroscopy, colorimetric, and image analysis. Foods 2018, 7, 152. [CrossRef]

35. Kabrite, S.; Bou-Mitri, C.; Fares, J.E.H.; Hassan, H.F.; Boumosleh, J.M. Identification and dietary exposure assessment of tetracycline and penicillin residues in fluid milk, yogurt, and labneh: A cross-sectional study in Lebanon. Veter. World 2019, 12, 527-534. [CrossRef]

36. Triki, M.; Herrero, A.M.; Jiménez-Colmenero, F.; Ruiz-Capillas, C. Quality assessment of fresh meat from several species based on free amino acid and biogenic amine contents during chilled storage. Foods 2018, 7, 132. [CrossRef]

37. Choi, S.Y.; Kwon, N.J.; Kang, H.S.; Kim, J.; Cho, B.H.; Oh, J.H. Residues determination and dietary exposure to ethoxyquin and ethoxyquin dimer in farmed aquatic animals in South Korea. Food Control 2020, 111, 107067. [CrossRef]

38. Ramatla, T.; Ngoma, L.; Adetunji, M.; Mwanza, M. Evaluation of Antibiotic Residues in Raw Meat Using Different Analytical Methods. Antibiotics 2017, 6, 34. [CrossRef] [PubMed]

39. Schug, T.T.; Janesick, A.; Blumberg, B.; Heindel, J.J. Endocrine disrupting chemicals and disease susceptibility. J. Steroid Biochem. Mol. Biol. 2011, 127, 204-215. [CrossRef] [PubMed]

40. Gaugain-Juhel, M.; Delepine, B.; Gautier, S.; Fourmond, M.P.; Gaudin, V.; Hurtaud-Kohanski, M.A.; DePristo, M.A.; Collins, J.J. Sublethal antibiotic treatment leads to multidrug resistance via radical-induced mutagenesis. Mol. Cell 2010, 37, 311-320. [CrossRef]

41. Baynes, R.E.; Dedonder, K.; Kissell, L.; Mzyk, D.; Marmulak, T.; Smith, G.; Tell, L.; Gehring, R.; Davis, J.; Riviere, J.E. Health concerns and management of select veterinary drug residues. Food Chem. Toxicol. 2016, 88, 112-122. [CrossRef] [PubMed]

42. Li, N.; Ho, W.K.; Ying, G.G.; Deng, W.J. Veterinary antibiotics in food, drinking water, and the urine of preschool children in Hong Kong. Environ. Int. 2017, 108, 246-252. [CrossRef]

43. Ji, K.; Kho, Y.; Park, Y.; Choi, K. Influence of a five-day vegetarian diet on urinary levels of antibiotics and phthalate metabolites: A pilot study with "Temple Stay" participants. Environ. Res. 2010, 110, 375-382. [CrossRef]

44. Ji, K.; Kho, Y.; Park, C.; Paek, D.; Ryu, P.; Paek, D.; Kim, M.; Kim, P.; Choi, K. Influence of water and food consumption on inadvertent antibiotics intake among general population. Environ. Res. 2010, 110, 641-649. [CrossRef] [PubMed]

45. Cox, L.M.; Blaser, M.J. Antibiotics in early life and obesity. Nat. Rev. Endocrinol. 2014, 11, 182-190. [CrossRef] [PubMed]

46. Cox, L.M.; Yamanishi, S.; Sohn, J.; Alekseyenko, A.V.; Leung, J.M.; Cho, I.; Kim, S.G.; Li, H.; Gao, Z.; Mahana, D.; et al. Altering the intestinal microbiota during a critical developmental window has lasting metabolic consequences. Cell 2014, 158, 705-721. [CrossRef] [PubMed]

47. Kyriakides, D.; Panderi, I.; Hadjigeorgiou, M.; Christou, K.; Maou, M.; Kavantzas, N.; Lazaris, A. Veterinary antimicrobial residues in pork meat in Cyprus: An exposure assessment. J. Food Compos. Anal. 2020, 90, 103512. [CrossRef]

48. Pikkemaat, G.M. Microbial screening methods for detection of antibiotic residues in slaughter animals. Anal. Bioanal. Chem. 2009, 395, 893-905. [CrossRef]

49. CYSTAT. Population Statistics, Series II, Demographic Report No 53, pp 58, Table 28. Republic of Cyprus, Statistical Service. Available online: http://www.cystat.gov.cy/mof/cystat/statistics.nsf/All/ C106FD0599F64191C22583550034275E/\$file/DEMOGRAPHIC_REPORT-2016-271117.pdf?OpenElement (accessed on 1 March 2020).

50. EFSA. Management of left-censored data in dietary exposure assessment of chemical substances. EFSA J. 2010, 8, 1-92. 
51. Savva, C.S.; Kourides, A.Y.; Hadjigeorgiou, C.; Tornaritis, J.M. Overweight and obesity prevalence and trends in children and adolescents in Cyprus 2000-2010. Obes. Res. Clin. Pract. 2014, 8, e426-e434. [CrossRef]

52. Kroes, R.; Muller, D.; Lambe, J.; Lowik, M.; Van Klaveren, J.; Kleiner, J.; Massey, R.; Mayer, S.; Urieta, I.; Verger, P.; et al. Assessment of intake from the diet. Food Chem. Toxicol. 2002, 40, 327-385. [CrossRef]

53. Magnér, J.; Wallberg, P.; Sandberg, J.; Cousins, A.P. Human Exposure to Pesticides from Food. A Pilot Study; On behalf of: Coop Sverige AB, Report number U 5080; IVL Swedish Environmental Research Institute: Stockholm, Sweden, 2015.

Publisher's Note: MDPI stays neutral with regard to jurisdictional claims in published maps and institutional affiliations.

(C) 2020 by the authors. Licensee MDPI, Basel, Switzerland. This article is an open access article distributed under the terms and conditions of the Creative Commons Attribution (CC BY) license (http://creativecommons.org/licenses/by/4.0/). 